\title{
Evaluate of heavy metal concentration in shrimp (Penaeus semisulcatus) and crab (Portunus pelagicus) with INAA method
}

\author{
Marzieh Heidarieh ${ }^{1 *}$, Mohammad Ghannadi Maragheh², Mehrdad Azizi Shamami², Mehdi Behgar', \\ Farhood Ziaei ${ }^{1}$ and Zahra Akbari ${ }^{2}$
}

\begin{abstract}
The level of the heavy metal in green tiger shrimp (Penaeus semisulcatus) and crab (Portunus pelagicus) caught off the Persian Gulf near Bushehr province were investigated. This study was performed to evaluate instrumental neutron activation analysis (INAA) to analyze heavy metal concentration in crab and shrimp whole body tissue. The order of the swimmer crab and shrimp heavy metal concentrations were $\mathrm{Zn}>\mathrm{Fe}>\mathrm{As}>\mathrm{Mn}>\mathrm{Co}$ and $\mathrm{Fe}>\mathrm{Zn}>\mathrm{Mn}>\mathrm{As}>\mathrm{Co}$, respectively. The results showed swimmer crab (Portunus pelagicus) and shrimp (Penaeus semisulcatus) caught off Persian gulf, were contaminated with high level of As $(21.38 \pm 3.31 \mathrm{ppm}$ and $8.28 \pm 2.82 \mathrm{ppm}$, respectively). High levels of As and Mn were noted in crabs and shrimp, respectively.
\end{abstract}

Keywords: Heavy metal, Crab, Shrimp, Persian gulf, Neutron activation

\section{Introduction}

Heavy metal pollutions are particularly hazardous contaminants in food and the environment. In general, they are not biodegradable and have long biological halflives. According to the World Health Organization (World Health Organization 1995) heavy metals must be controlled in food sources in order to assure public safety. Excessive concentration of food heavy metals is associated with the etiology of a number of diseases, especially cardiovascular, renal, neurological, and bone diseases (Chailapakul et al. 2008). A major reason to monitor levels of toxic metals in foods follows from the fact that contamination of the general environment has increased.

It is known that some shrimp and crab may provide useful means of monitoring such elemental concentration levels and their impact on the aquatic environment. In 2005 BU-Olayan and Thomas showed higher trace metal levels in benthic molluscs and annelids of Kuwait Bay in the Persian Gulf compared to other regions of the word. Al-Mohanna and Subrahmanyam (2001) demonstrated

\footnotetext{
* Correspondence: mheidarieh@nrcam.org

${ }^{1}$ Agricultural, Medical and Industrial Research School (AMIRS-NSTRI), Karaj, Iran

Full list of author information is available at the end of the article
}

$\mathrm{Zn}$ and $\mathrm{Cu}$ pollution swimmer crabs and attributed this to the 1991 Gulf War oil spill into Kuwait's marine environment. Alyahya et al. (2011) reported that concentrations of $\mathrm{Cd}, \mathrm{Pb}, \mathrm{Cu}$, and $\mathrm{Zn}$ in fresh parts of the clam $(\mathrm{M}$. meretrix) in the Persian Gulf near the Saudi Arabia coast line were within the acceptable standard range. To the extent of the author's knowledge, few studies reported heavy metals pollution of shrimp and fish in the Persian Gulf water of Iran (Pourang et al. 2005; Raissy et al. 2011).

Detection methods of stable elements included colorimetry, spectrography, mass spectroscopy, atomic absorption, spectrophotometry, and neutron activation analysis (NAA). Of these methods NAA has advantages over alternative methods. Detection sensitivity are greatest $(<0.01$ $\mathrm{ppm}$ ) with neutron activation analysis (NAA) (Corliss 1963) and NAA also allows for simultaneous detection of many other metals in a sample. There is no need to sample preparation (i.e. dry ashing or wet ashing) before the analysis and intact samples can be used for analysis. Instrumental neutron activation analysis (INAA) has been successfully used to investigate heavy metals of many biological materials such as food and freshwater fish (Cunningham and Stroube 1987; Ndiokwere 1983) and also used to determine the body composition of salmon (Talbot et al. 1986). 


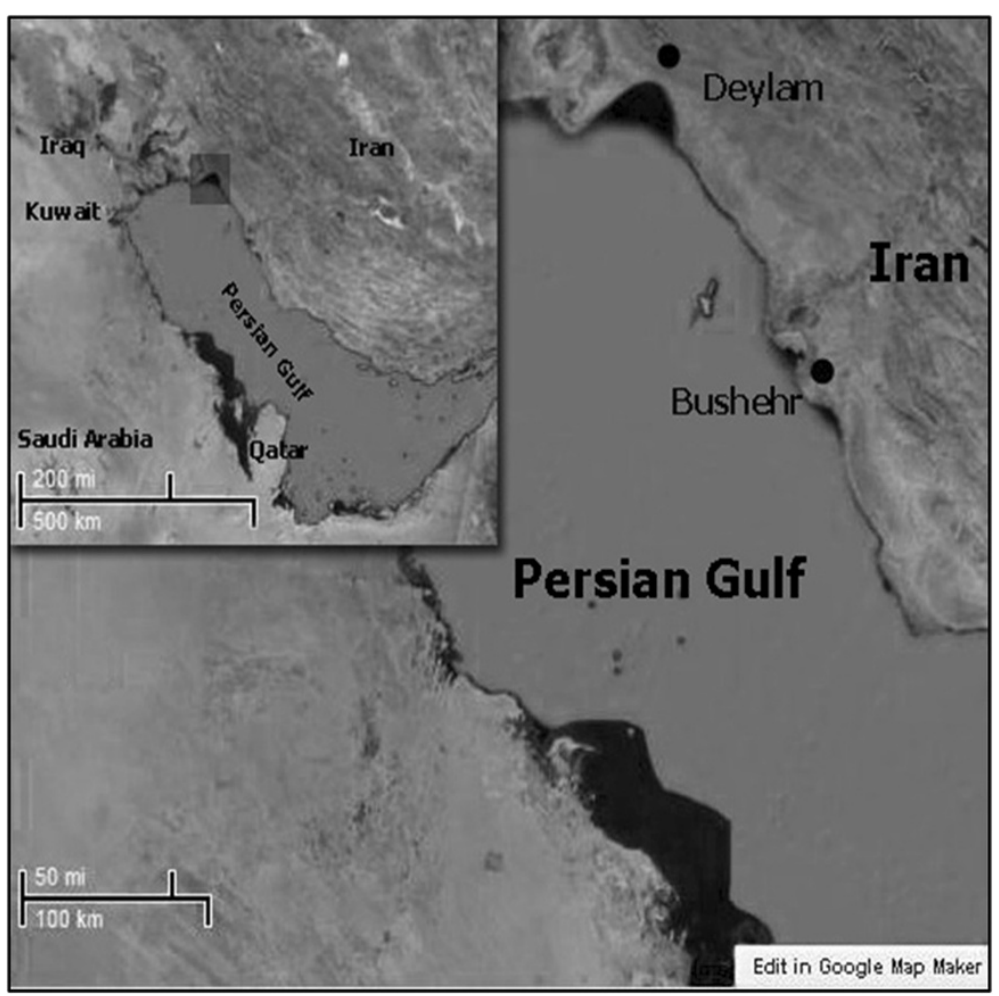

Figure 1 Location map of sampling site, Deylam port, near Bushehr province area of Iran.

This study is aimed in determining the concentrations of the heavy metal contamination ( $\mathrm{Mn}, \mathrm{Fe}, \mathrm{Zn}, \mathrm{Co}$ and As) in green tiger shrimp (Penaeus semisulcatus) and blue crab (Portunus pelagicus) by using instrumental neutron activation analysis (INAA).

\section{Material and methods}

\section{Collection and preparation of samples}

Swimmer crab (Portunus pelagicus) and shrimp (Penaeus semisulcatus) were captured in depth 41-42 m - Deylam port (Figure 1) by using cast nets during spring of 2011. At this study used 10 same sample size, shrimp (10-12 g) and Crab (11-13 g). Immediately, after sampling crab and shrimp were stored in a container, preserved in crushed ice and transferred to the laboratory and frozen $-20^{\circ} \mathrm{C}$ until analyzed.

Samples (whole body) were dried $\left(60^{\circ} \mathrm{C}\right.$ for $\left.72 \mathrm{~h}\right)$ and ground through a $2 \mathrm{~mm}$ screen for subsequent INAA. The 500-600 mg of dried samples and standard (Fish Tissue, IAEA-407) were accurately weighed into polyethylene vials and heat sealed for irradiation.

\section{Irradiation and counting}

The irradiation of the samples and standard were carried out in the 40-tube specimen rack of the Tehran Research Reactor (Pool Type Reactor) at a neutron flux of $1.0 \times$ $10^{13} \mathrm{n} / \mathrm{cm} / \mathrm{s}$. Each analytical portion was irradiated twice, once to analyze for elements yielding short-lived radioisotopes and a second time to analyze for elements yielding long-lived radioisotopes. Table 1 lists the radioisotopes, half-lives and gamma-ray lines used.

For short-lived radioisotopes, samples were irradiated for 10 seconds and counted 4 minutes later for 300 seconds and again 2 hours later for 1000 seconds. For long-lived radioisotopes, samples were irradiated for 1 hour (3600 s) and counted 3 days later for 1000 seconds and also 10 days later for 3000 seconds and 24 days later for 5000 seconds.

The samples and the standard were counted on the high pure germanium detector (resolution $1332.5 \mathrm{keV}$ at $2.0 \mathrm{keV}$ and efficiency of $20 \%$ ).

Table 1 Radioisotopes, half-lives and gamma-ray energies used

\begin{tabular}{lcc}
\hline Isotope & Half-life & Gamma-ray energies (keV) \\
\hline${ }^{56} \mathrm{Mn}$ & $155 \mathrm{~min}$ & $846.76,1810.72$ \\
\hline${ }^{59} \mathrm{Fe}$ & $44.5 \mathrm{~d}$ & $1099.25,1291.60$ \\
\hline${ }^{60} \mathrm{Co}$ & $5.27 \mathrm{y}$ & $1173.2,1332.50$ \\
\hline${ }^{76} \mathrm{As}$ & $1.10 \mathrm{~d}$ & 559.10 \\
\hline${ }^{65} \mathrm{Zn}$ & $243.9 \mathrm{~d}$ & 1115.55 \\
\hline${ }^{69 \mathrm{~m}} \mathrm{Zn}$ & $825.6 \mathrm{~min}$ & 438.63 \\
\hline${ }^{71 \mathrm{~m}} \mathrm{Zn}$ & $236.4 \mathrm{~min}$ & 386.28 \\
\hline
\end{tabular}


Table $2 \mathrm{Mn}, \mathrm{Fe}, \mathrm{Zn}, \mathrm{Co}$ and As concentrations (means $\pm \mathrm{s}$ ) in crab and shrimp samples (ppm/dry whole body)

\begin{tabular}{lcc}
\hline Metal & Crab & Shrimp \\
\hline $\mathrm{Mn}$ & $1.91 \pm 0.33$ & $25.43 \pm 2.95$ \\
\hline As & $21.38 \pm 3.31$ & $8.28 \pm 2.82$ \\
\hline $\mathrm{Co}$ & $0.15 \pm 0.02$ & $0.40 \pm 0.05$ \\
\hline $\mathrm{Fe}$ & $62.87 \pm 11.07$ & $288 \pm 38.88$ \\
\hline $\mathrm{Zn}$ & $66.64 \pm 7.60$ & $68.73 \pm 7.84$ \\
\hline
\end{tabular}

\section{Statistical analysis}

The results were subjected to emulate and analysis using Maestro II and SPAN, respectively.

Animal Dead tissues handling was performed with regard to Iranian animal ethics society and local university rules.

\section{Results and discussion}

The Mn, Fe, Zn, Co and As levels were determined in the whole body of the swimmer crab and green tiger shrimp (Table 2). There are remarkable differences in the swimmer crab and green tiger shrimp heavy metal concentrations. The order of the heavy metal concentrations in swimmer crab was found: $\mathrm{Zn}>\mathrm{Fe}>\mathrm{As}>\mathrm{Mn}>\mathrm{Co}$, while in whole body of green tiger shrimp was $\mathrm{Fe}>\mathrm{Zn}>\mathrm{Mn}>\mathrm{As}>\mathrm{Co}$.

The swimmer crab heavy metal concentrations were less than shrimp samples, with the exception of As. The As concentration were 18.07-24.69 and 5.46-11.10 ppm in whole body of crab and shrimp, respectively.

Pourang et al. (2005) examined green tiger shrimp heavy metal distribution in the northwestern (near the Bushehr Province coastline) part of the Persian Gulf. In this study highest mean of $\mathrm{Zn}$ concentration (43.39 ppm/fresh weight) was found in hepatopancreas. Also, the $\mathrm{Zn}$ levels of the exoskeleton and muscle were 8.56 and $8.98 \mathrm{ppm} /$ wet weight, respectively. In the current study, the level of the $\mathrm{Zn} /$ fresh weight of whole body was $22.76 \mathrm{ppm}$.

Research on swimmer crab in turkey showed $\mathrm{Zn}, \mathrm{Mn}$ and Fe levels of swimmer crab were 37.2-46.8, 1.30-1.9 and 4.5-6.8 ppm of dry body meat, respectively (Gökoğlu and Yerlikaya 2003). Also, Gökoğlu and Yerlikaya (2003) showed the Fe level of the swimmer crab was higher than results found in the current study.

Sadiq et al. (1982) reported levels of $\mathrm{Zn}$ and Co are 165.73 and $4.66 \mathrm{ppm} /$ dry crab whole body, respectively. These values are markedly higher than levels obtained in the current study (66.64 and $0.16 \mathrm{ppm}$, respectively).

Ayas and Özoğul (2011) showed the concentration of the $\mathrm{Zn}$ and Fe were 101.40-104.13 and 21.92-23.90 ppm for male, and 106.13-108.64 and 13.15-16.53 ppm for female swimmer crab, respectively.

The mean values of the heavy metals contents in edible tissue and whole body of crab (Portunus pelagicus) and shrimp (Penaeus semisulcatus) have been summarized at Table 3. Data obtained from current study indicated that heavy metal contents in crab and shrimp are comparable to the other parts of Persian Gulf and world areas. According to available literature, there is no study on Mn concentration in shrimp tissue.

Although, in the current study was measured $\mathrm{Zn}$ and Mn concentration 56.39-221.68 and 0.14-2.01 ppm, respectively.

Conversely, in study by Al-Mohanna and Subrahmanyam (2001), determined maximum values for As was about 36 times higher than the value was reported.

In most studies the heavy metal concentration are reported either in various body parts of crustaceans or in their edible tissue. However in current study whole body samples were used. Firat et al. (2008) reported higher concentration of heavy metals in hepatopancreas compared to the gill and muscle of shrimp, similar results were reported

Table 3 Comparison of mean concentrations of trace metals reported for shrimp (Penaeus semisulcatus) and crab (Portunus pelagicus) in the worldwide

\begin{tabular}{|c|c|c|c|c|c|c|c|}
\hline Location & Tissue & Mn & $\mathrm{Fe}$ & $\mathrm{Zn}$ & As & Co & Reference \\
\hline \multicolumn{8}{|l|}{ Crab } \\
\hline Persian Gulf, Iran & Whole body & 1.91 & 62.87 & 66.64 & 21.38 & 0.15 & Present study \\
\hline Persian Gulf, Kuwait & Muscle & 0.95 & - & 206.0 & 0.31 & - & Al-Mohanna and Subrahmanyam 2001 \\
\hline Mersin bay, Turkey & Muscle & - & 18.93 & 104.82 & - & - & Ayas and Özoğul 2011 \\
\hline Persian Gulf, Saudi Arabia* & Whole body & - & - & 165.73 & - & 4.66 & Sadiq et al. 1982 \\
\hline \multicolumn{8}{|l|}{ Shrimp } \\
\hline Persian Gulf, Iran & Whole body & 25.43 & 288.0 & 68.73 & 8.28 & 0.40 & Present study \\
\hline Iskenderun bay, Turkey ${ }^{1}$ & Muscle & - & 18.69 & 27.75 & - & - & Firat et al. 2008 \\
\hline Persian Gulf, Iran* & Muscle & - & - & 41.76 & - & - & Pourang et al. 2005 \\
\hline Persian Gulf, Saudi Arabia* & Whole body & - & - & 148.89 & - & 4.56 & Sadiq et al. 1982 \\
\hline
\end{tabular}

Values are expressed in ppm per dry weight either of edible tissue or whole body.

1 Mean of males and females.

2 Mean of four stations.

* The values calculated based on dry matter content of these species from the metal concentration per wet weight of shrimp and crab. 
by Pourang et al. (2005). Hence the heavy metal concentrations of muscle in shrimp and crab samples in the current study might be lower than the reported values.

Sadiq et al. (1982) reported $\mathrm{Zn}$ and Co concentrations in shrimp as $148 \mathrm{ppm}$ and $4.56 \mathrm{ppm}$, respectively. The average Co content was determined as $0.15 \mathrm{ppm}$ and $0.40 \mathrm{ppm}$ in the swimmer crab and shrimp, respectively.

Level of As in the whole body of swimmer crab in the current study was higher than previous studies that reported As concentration in lobster, bivalves, crabs and fishes of Persian gulf (Mora et al. 2004; Al-Mohanna and Subrahmanyam 2001; Raissy et al. 2011). Levels of As contamination in the Persian Gulf may have affected these values. Major anthropogenic sources of arsenic include mining and smelting operations, emissions from coal burning electrical generating facilities, leaching from hazardous waste facilities and from insecticide, herbicide or algicide applications (Anonymous 2009).

Among these sources, herbicide and algicide may have major importance. In recent years local use of algicide against algae bloom has been increased. However, the majority of the As in shrimp and crab appears to be in the form of the less toxic organic form, for example the predominant form is arsenobetaine (Shiomi et al. 1984; Sloth et al. 2005). For this reason, the determination of the total amount of the arsenic in a sample is not sufficient to assess the risk from eating seafood, and speciation analysis is necessary.

High levels of $\mathrm{Mn}$ in shrimp samples were noted when compared to crab samples (25.43 ppm vs $1.91 \mathrm{ppm})$. In a geochemistry study of sediment core of Persian gulf near Bushehr port not only Mn level among selected trace metals was highest, but also the heavy metals concentration were higher than mean crust and mean world sediments (Karbassi et al. 2005; Fazaeli 2010). With the exception of the As, levels of other heavy metals were higher in shrimp compared to crabs. In contrast to these results Sadiq et al. (Sadiq et al. 1982) showed higher heavy metals accumulation in crabs compared to shrimp.

The results showed swimmer crab (Portunus pelagicus) and shrimp (Penaeus semisulcatus) have been contaminated with heavy metals. Shrimp showed a higher potential to accumulate metals in their body compared to crabs. Further studies are necessary to evaluate the effect of organs, sex, size, season and site of sampling on heavy metal concentration in crab and shrimp. More speciation analysis is also necessary to determination of $\mathrm{Pb}, \mathrm{Hg}$, total and organic forms of arsenic.

\section{Competing interests}

The authors report no conflicts of interest. The authors alone are responsible for the content and writing of the paper.

\section{Authors' contributions}

$\mathrm{MH}$ and MGM participated in the design of the study and manuscript preparation. MAS and FZ participated in data acquisition and statistical analysis. MB participated in manuscript revision. ZA participated in data acquisition and technical assistance. $\mathrm{MH}$ reviewed the manuscript and provided advice. All authors read and approved the final manuscript.

\section{Acknowledgements}

The authors are grateful for the financial support provided by Agricultural, Medical and Industrial Research School (AMIRS-NSTRI), Karaj, Iran.

\section{Author details}

'Agricultural, Medical and Industrial Research School (AMIRS-NSTRI), Karaj, Iran. ${ }^{2}$ Nuclear Science and Technology Research Institute (NSTRI), Tehran, Iran.

Received: 17 November 2012 Accepted: 30 January 2013

Published: 28 February 2013

\section{References}

Al-Mohanna SY, Subrahmanyam MNV (2001) Flux of heavy metal accumulation in various organs of the intertidal marine blue crab, Portunus pelagicus (L.) from the Kuwait coast after the Gulf War. Environ Int 27(4):321-326. doi:10.1016/ S0160-4120(01)00063-0

Alyahya H, El-Gendy AH, Al Farraj S, El-Hedeny M (2011) Evaluation of Heavy Metal Pollution in the Arabian Gulf Using the Clam Meretrix meretrix Linnaeus, 1758. Water Air Soil Poll 214:499-507. doi:10.1007/s11270-010-0441-x

Anonymous (2009) Mercury, Lead, Cadmium, Tin and Arsenic in Food. Toxicology Fact Sheet Series 1:1-13

Ayas D, Özoğul Y (2011) The chemical composition of sexually mature blue swimmer crab (Portunus pelagicus, Linnaeus 1758) in the Mersin Bay. J Fish Sci 5(4):308-316. doi:10.3153/ffscom.2011035

BU-Olayan AH, Thomas BV (2005) Validating Species Diversity OF Benthic Organisms to trace metal pollution in Kuwait bay, off the Arabian Gulf. Appl Ecol Environment Res 3(2):93-100

Chailapakul O, Korsrisakul S, Siangproh W, Grudpan K (2008) Fast and simultaneous detection of heavy metals using a simple and reliable microchip-electrochemistry route: An alternative approach to food analysis. Talanta 74:83-689. doi:10.1016/j.talanta.2007.06.034

Corliss WR (1963) Neutron activation analysis from "Understanding the atom". US At Energy Comm, Washington, DC

Cunningham WC, Stroube WB (1987) Application of an instrumental neutron activation analysis procedure to analysis of food. Sci Total Environment 63:29-43. doi:10.1016/0048-9697(87)90034-9

De Mora S, Fowler SW, Wyse E, Azemard S (2004) Distribution of heavy metals in marine bivalves, fish and coastal sediments in the Gulf and Gulf of Oman. MarPollut Bull 49:410-424. doi:10.1016/j.marpolbul.2004.02.029

Fazaeli A (2010) Geochemistry of core sediment off Bushehr, Persian Gulf. 2nd International Symposium on Contaminated Sediments Chemical Characterization, pp 213-216

Firat Ö, Gök G, Çoğun HY, Yüzereroğlu TA, Kargin F (2008) Concentrations of Cr, $\mathrm{Cd}, \mathrm{Cu}, \mathrm{Zn}$ and $\mathrm{Fe}$ in crab Charybdis longicollis and shrimp Penaeus semisulcatus from the Iskenderun Bay, Turkey. Environ Monit Assess 147:117123. doi:10.1007/s10661-007-0103-7

Gökoglu N, Yerlikaya P (2003) Determinaton of proximate composition and mineral contents of blue crab (Callinectes sapidus) and swim crab (Portunus pelagicus) caught off the Gulf of Antalya. Food Chem 80(4):495-498. doi:10.1016/50308-8146(02)00318-7

Karbassi AR, Nabi-Bidhendi GhR B (2005) Environmental geochemistry of heavy metals in a sediment core off Bushehr, Persian Gulf. Iran J Environ Health Sci Eng 2(4):255-260, http://journals.tums.ac.ir/abs/2572

Ndiokwere CL (1983) Arsenic, Gold and Mercury Concentration Levels in Freshwater Fish by Neutron Activation Analysis. Environ Pollut B 6:263-269. doi:10.1016/0143-148X(83)90013-7

Pourang N, Dennis JH (2005) Distribution of trace elements in tissues of two shrimp species from the PersianGulf and roles of metallothionein in their redistribution. Environ Int 31(3):325-341. doi:10.1016/j.envint.2004.08.003

Raissy M, Ansari M, Rahimi E (2011) Mercury, arsenic, cadmium and lead in lobster (Panulirus homarus) from the Persian Gulf. Toxicol Ind Health 27 (7):655-659. doi:10.1177/0748233710395346

Sadiq M, Zaidi TH, Hoda A, Mian AA (1982) Heavy Metal Concentrations in Shrimp, Crab, and Sediment Obtained from AD-Dammam Sewage Outfall Area. B Environ Contam Tox 29:313-319. doi:10.1007/BF01706234 
Shiomi K, Shinagawa A, Igarashi T, Yamanaka H, Kikuchi T (1984) Evidence for the presence of arsenobetaine as a major arsenic compound in the shrimp Sergestes lucens. Cell Mol Life Sci 40(11):1247-1248. doi:10.1007/BF01946656

Sloth JJ, Larsen EH, Julshamn K (2005) Survey of Inorganic Arsenic in Marine Animals and Marine Certified Reference Materials by Anion Exchange HighPerformance Liquid Chromatography-Inductively Coupled Plasma Mass Spectrometry. J Agric Food Chem 53(15):6011-6018. doi:10.1021/jf047950e

Talbot C, Preston T, East BW (1986) Body composition of Atlantic salmon (Salmo salar L.) studied by neutron activation analysis. Compa Biochem Physiol A 85 (3):445-450. doi:10.1016/0300-9629(86)90427-5

WHO (1995) Lead Environmental Health Criteria. WHO, Geneva

doi:10.1186/2193-1801-2-72

Cite this article as: Heidarieh et al:: Evaluate of heavy metal

concentration in shrimp (Penaeus semisulcatus) and crab (Portunus pelagicus) with INAA method. SpringerPlus 2013 2:72.

\section{Submit your manuscript to a SpringerOpen ${ }^{\circ}$ journal and benefit from:}

- Convenient online submission

- Rigorous peer review

- Immediate publication on acceptance

- Open access: articles freely available online

- High visibility within the field

- Retaining the copyright to your article

Submit your next manuscript at $\boldsymbol{\triangleright}$ springeropen.com 